TARNOWSKIE STUDIA TEOLOGICZNE 35 (2016) NR 2, S. 169-173

http://dx.doi.org/10.15633/tst.2113

ks. Tadeusz Brzegowy

UNIWERSYTET PAPIESKI JANA PAWEA II W KRAKOWIE

\title{
Laudacja na 7o-lecie ks. prof. dr. hab. Antoniego Paciorka z okazji wręczenia księgi jubileuszowej \\ (Tarnów, 7 marca 2016 roku)
}

Wielce Czcigodny Solenizancie-Jubilacie!

Dostojni Członkowie Rady Wydziału Teologicznego UPJPII w Tarnowie z jej Dziekanem, Szanowny Księże Rektorze wsD w Tarnowie, Czcigodni Profesorowie!

Drodzy Studenci!

Wysoka Rada wT w Tarnowie UPJPII w Krakowie postanowiła uczcić Jubileusz 7o-lecia życia Księdza Profesora specjalną księgą pamiątkową. Materiały zostały zebrane, księga została wydrukowana i dziś ma się dokonać jej uroczyste wręczenie Księdzu Jubilatowi. Okazja jest podniosła i uroczysta. Wypada nam więc po krótce zobaczyć i przybliżyć zasługi i dorobek dydaktyczny i naukowy Księdza Jubilata, a jest on pod każdym względem bogaty, wprost imponujący.

W pracy dydaktycznej i naukowej ks. Paciorka są dwa okresy: tarnowski i lubelski.

Po studiach specjalistycznych na KUL-u i Papieskim Instytucie Biblijnym w Rzymie ks. Paciorek w roku 1978 podjął pracę wykładowcy w wsD w Tarnowie, gdzie wykładał introdukcję ogólną do Pisma Świętego i egzegezę pism św. Pawła. Do tych dyscyplin napisał i opublikował podręczniki. Prowadził też lektoraty z języka łacińskiego i greckiego. Już wtedy spożytkował swoje przygotowanie filologiczne, składając do druku przekłady Arystotelesa, pt. Meteorologia. O świecie, PWN 1982. Był to czas przygotowania polskiej edycji Liturgii godzin (brewiarza) i na prośbę Komisji Episkopatu Polski Ksiądz Jubilat sporządził przekłady czytań hagiograficznych do tomów 3-4. Do tych czytań opracował też komentarze pt. „Umocnieni słowem. Czytania Liturgii godzin, t. 1-4, Katowice 1986-89; do tego należy dodać opracowanie: Biblia dla każdego i na każdy dzień. Stary Testament, Pallottinum 1995. 
Po habilitacji nt. „Człowiek bez Chrystusa w soteriologii Listu św. Pawła do Rzymian” (Tarnów 1995) rozpoczął pracę wykładowcy, a następnie profesora na KUL-u w 1996 roku. Obok pracy dydaktycznej intensywnie prowadził swe badania naukowe i wydawał publikacje. W serii Biblia Lubelska opublikował komentarze do Listu do Hebrajczyków (1999) i Ewangelii według św. Jana (2000).

Na szczególną uwagę zasługuje nowa seria komentarzy do całego Pisma Świętego. Od dłuższego czasu była odczuwana i sygnalizowana potrzeba opracowania nowego komentarza naukowego do Pisma Świętego, gdyż seria zainicjowana przez ks. prof. S. Łacha i E. Dąbrowskiego na KUL-u w latach 6o. zestarzała się i wciąż była nieukończona. Zapotrzebowanie dotyczyło komentarza napisanego w oparciu o metodę historyczno-krytyczną, jaką stosują prawie wszystkie dzisiejsze komentarze naukowe, i wykorzystującego olbrzymki dorobek egzegezy światowej ostatnich dziesięcioleci. Toteż gdy ks. Paciorek taką ideę podjął, wielu egzegetów przystąpiło do niej z entuzjazmem. Trzeba jednak było znaleźć wydawnictwo dla tej dość niekomercyjnej inicjatywy. Należy bowiem pamiętać, że nie wspiera jej żadna uczelnia czy instytucja (jak to jest zazwyczaj). I tu, opatrznościowo, zgłosiło się Wydawnictwo św. Pawła, które wcześniej ukończyło prace nad nowym przekładem Biblii z notami i komentarzami do poszczególnych perykop (w której to edycji ks. Paciorek wziął udział jako tłumacz i komentator). Ksiądz Paciorek zdołał zdobyć słowo wstępne i błogosławieństwo papieża (już bardzo chorego), dzisiejszego świętego Jana Pawła II. W dziesięć lat od wydania pierwszego tomu (Ewangelia według świętego Mateusza, cz. 1, wstęp, przekład z oryginału, komentarz A. Paciorek [Nowy Komentarz Biblijny, 1], Częstochowa 2005) ukazało się 30 tomów komentarza (z przewidzianych 50), i już dzisiaj w bibliotekach uniwersyteckich dzieło zajmuje poczesne miejsce. W Papieskim Instytucie Biblijnym w Rzymie komentarz znajduje się w głównej czytelni wśród najlepszych serii światowych, na wysokości oczu, widzialny i łatwo dostępny dla wszystkich. Korzystają zeń nie tylko biblioteki uniwersyteckie. Ksiądz proboszcz parafii św. Maksymiliana w Tarnowie kupuje komentarz i eksponuje go w kancelarii parafialnej, gdzie mogą z niego korzystać wszyscy współpracownicy, a także parafianie. Jest to wielkie dzieło i pozostanie na lata instrumentem pracy naukowców, jak i duszpasterzy, a także świadectwem odwagi i zaangażowania, dość bezinteresownego, wielu polskich egzegetów. Za inicjatywę i za kontynuowanie tej pracy należą się Księdzu Profesorowi słowa wielkiego uznania. 
Nowszą inicjatywą było zainicjowanie serii pt. Scripturae Lumen, w ramach której ukazuje się już 7 tom. Jej założeniem jest wydanie co roku tomu poświęconego konkretnemu tematowi teologicznemu i omówienie go z punktu widzenia różnych dyscyplin, głównie teologicznych, ale nie tylko. Celem jest ukazanie głębi przesłania biblijnego oraz jego oddziaływania na inne dziedziny życia umysłowego człowieka, jak literatura, sztuka, filozofia. Zgodnie z tym założeniem trzeba do poszczególnych tomów szukać specjalistów z różnych dziedzin nauk teologicznych i humanistycznych. Korzyści z takiego opracowania są ogromne; pokazują one jak wielkie i jak wielostronne oddziaływanie ma słowo objawione, które w dzisiejszej nowoczesnej ideologii nieraz bywa marginalizowane czy nawet eliminowane. Warto zauważyć, że od roku 2015, to znaczy od czasu kiedy Ksiądz Jubilat kończy 70 lat, seria jest opracowywana w ramach wT UPJPII w Tarnowie.

Zapewne za dzieło swego życia Ksiądz Jubilat uważa najnowszą książkę pt. Jezus $z$ Nazaretu. Czasy i wydarzenia, wyd. św. Pawła 2014. Jest to dzieło godne uwagi, bowiem dotychczas w języku polskim czytelnik był skazany na tłumaczenia dzieł literatury zagranicznej (włoskie, niemieckie, francuskie), natomiast nie było podobnego opracowania w języku polskim. Publikacja ta adresowana jest do szerszego kręgu odbiorców, niemniej jednak opracowana $\mathrm{z}$ wykorzystaniem najnowszych metod badawczych nad życiem Jezusa i nad Ewangeliami w oparciu o dane historyczne czy archeologiczne. Jako przygotowanie do tego dzieła finalnego posłużyły liczne prace cząstkowe, poświęcone życiu i nauce Jezusa z Nazaretu, a są to następujące publikacje: Q-Ewangelia Galilejska, Lublin 2001; Gdy Jezus narodzit się w Betlejem... Ewangelia dzieciństwa z komentarzem biblijno-teologicznym i ikonograficznym, Lublin 20o6; Męka Pana naszego Jezusa Chrystusa według ewangelii św. Mateusza z komentarzem biblijno-teologicznym i ikonograficznym, Lublin 2007; Tobie mówię: wstań! Cuda Jezusa w ewangeliach $z$ komentarzem biblijno-teologicznym i ikonograficznym, Tarnów 2009; Pan rzeczywiście zmartwychwstał! Nowotestamentalne orędzie o zmartwychwstaniu Jezusa z komentarzem biblijno-teologicznym i ikonograficznym, Tarnów 2010; Przypowieści Jezusa. Wprowadzenie i objaśnienie, Częstochowa 2013.

Przystępując do pracy nad Jezusem z Nazaretu, Autor musiał sobie na wstępie zadać pytanie: jak ten „problem” potraktować? W nowoczesnej nauce są bowiem zasadniczo dwa podejścia: można nań patrzeć poprzez kontemplację i wiarę - wtedy mówimy z perspektywy Jezusa wiary, ale jest też ujęcie z perspektywy Jezusa ziemskiego, innymi słowy Jezusa 
historycznego. Przez dodanie podtytułu czasy $i$ wydarzenia autor wskazał, że będzie go interesował Jezus, jaki żył w Palestynie I wieku naszej ery. Celem pracy ks. Paciorka jest możliwie staranne ukazanie Jezusa historycznego, które jednak nie abstrahuje od wiary w Jezusa (zob. wstęp księgi jubileuszowej). Głównym źródłem do poznania Jezusa historycznego są ewangelie, świadectwa ludzi i w jakiejś mierze społeczności wierzących pierwszego czy drugiego pokolenia, które uwierzyło i poszło za Zmartwychwstałym. Te świadectwa przybrały specjalną formę katechezy popaschalnej, gdzie wiara i historia splatają się nierozdzielnie. Długoletnie studia nad ewangeliami dały ks. Paciorkowi dogłębną wiedzę na temat form wyrazu, jakimi posłużyli się autorzy Nowego Testamentu, i dzięki temu duże możliwości docierania do jądra historycznego przekazów i ziemskiej postaci Jezusa.

Można żywić głęboką nadzieję, pisze ks. Paciorek w zakończeniu, że „praca ta pozwoli wielu czytelnikom nie tylko poznać lepiej Jezusa z Nazaretu, ale pójść za Nim, przylgnąć do Niego i oczekiwać przyjścia pełni Jego królestwa”.

W przedmowie do swego opracowania Ksiądz Jubilat wyraża nadzieję, „że niniejsza, niebędąca przekładem publikacja przybliży Czytelnikowi postać Jezusa Chrystusa, zaś nowotestamentalistów polskich zachęci do kolejnych, doskonalszych prób ukazania postaci Jezusa, o którym - czego dowodzą wspomniane liczne na całym świecie publikacje - numquam satis".

Dorobkiem ks. Paciorka są nie tylko książki i artykuły naukowe oraz wygłoszone referaty i wykłady. Są nim także ci, którzy czerpiąc odeń wiedzę i zapał naukowy, podjęli pracę wyrażoną w zdobywanych przez nich stopniach i tytułach naukowych. Pod kierunkiem ks. Profesora powstała pokaźna liczba prac z zakresu biblistyki: magisterskich, licencjackich i doktorskich (tych ostatnich 12).

Ksiądz Antoni Paciorek na swoją pracowitą emeryturę powrócił do Trzciany k. Bochni, gdzie się urodził i gdzie pobierał pierwsze nauki. Jest to parafia słynąca z wielkiej pobożności jej mieszkańców. Świadectwem religijności, jaka cechowała rodzinę Paciorków, może być fakt, że dwaj stryjowie Jubilata byli kapłanami diecezji tarnowskiej. Jeden to ks. Józef Paciorek, redaktor tygodnika „Nasza Sprawa”, zamordowany w Oświęcimiu w roku 1942, które$\mathrm{mu}$ ks. Antoni poświęcił piękną monografię pt. Słońce wśród chmur. Ksiądz Józef Paciorek - męczennik Oświęcimia, Tarnów 2006. Drugi stryj to ksiądz prałat Jan Paciorek, wybitny katecheta, wieloletni wykładowca katechetyki w wsD w Tarnowie, bardzo ceniony i lubiany przez kleryków. Od dzieciństwa Antoni Paciorek chodził do sąsiedzkiej Królówki na sławne odpusty ku czci 
Przemienienia Pańskiego i tam, być może, obudziło się w nim pragnienie głębszego poznania Ewangelii i wpatrywania się, wzorem Piotra, Jakuba i Jana, w jaśniejące oblicze Zbawiciela.

Nasz Ksiądz Jubilat Antoni Paciorek zasługuje w całej pełni na dostrzeżenie i uznanie jego wspaniałego dorobku naukowego, na wdzięczność ze strony środowiska naukowego w Tarnowie i Lublinie, na uważną lekturę licznych jego dzieł, poświadczonych pobożnym i gorliwym życiem kapłańskim. Czynimy to także dzisiaj, wręczając mu uroczyście księgę pamiątkową, zawierającą naukowy dorobek jego kolegów i uczniów. Ad multos annos Clarissime Amice! 